\title{
職員のための破傷風トキソイド接種プログラム
}

\author{
葛原 健太 ${ }^{1)}$ - 松井 泰子 ${ }^{1)}$. 宮崎 佳子 ${ }^{1)} \cdot$ 島谷 倫次 ${ }^{2)}$ \\ 高宮みさき ${ }^{2} \cdot$ 石井 範正 $^{3)} \cdot$ 堀内 智子 ${ }^{4)} \cdot$ 矢野 邦夫 $^{2)}$
}

\section{Vaccination Program of Tetanus Toxoid for Staff}

Kenta Kuzuhara ${ }^{1)}$, Yasuko Matsui ${ }^{11}$, Yosiko MiYazaKi ${ }^{1}$, Mititsugu Simatani ${ }^{2}$, Misaki TAKAMIYA ${ }^{2)}$, Norimasa ISHII ${ }^{3)}$, Tomoko HoRIUTI ${ }^{4)}$ and Kunio YANO ${ }^{2)}$

1) Department of Nursing, 2) Department of Infectious Disease and Infection Control, ${ }^{3)}$ Department of Pharmacy, ${ }^{4)}$ Department of Clinical Laboratory, Hamamatsu Medical Center

(2012 年 2 月 21 日 受付 $\cdot 2012$ 年 7 月 19 日 受理)

要旨

破傷風免疫獲得はすべての人に対し望まれ，医療従事者も外傷，人·動物咬傷，災害活動時の備 えとして破傷風免疫を獲得しておくことが望ましい.

当院で職員に対する破傷風トキソイド接種プログラムを実施した. ジフテリア・百日咳・破傷風 三種混合ワクチン (DPT ワクチン) 接種が開始となった 1968 年 4 月以前生まれの人は, 破傷風卜 キソイド 3 回接種, 1968 年 4 月以降に生まれた人は 1 回接種, DPT ワクチン接種不明の人は, 希 望により 3 回接種とした。結果は, 全職員を対象とした当院の破傷風トキソイド接種プログラム における破傷風トキソイド接種率は, $74.3 \%$ (754 人/1021 人)であった。職種別の破傷風トキソイ ド接種割合は，患者直接ケアの有無に関らず高かった。

破傷風トキソイドを接種した年代別割合は 20 歳代 $29.8 \%, 30$ 歳代 $32.4 \% ， 40$ 歳代 $17.2 \% ， 50$ 歳代 $17.4 \% ， 60$ 歳代 $3.2 \%$ であった．DPT 定期接種開始前に生まれた人を含む 40 歳代以上の破 傷風卜キソイド接種割合は $92.8 \%$ ( $285 / 307$ 人)であった．それ以外の年代の破傷風卜キソイド接 種割合は, $65.7 \%(469 / 714$ 人)であった。 副反応発生率は, 局所症状の発赤, 腫脹が多く久られた が，重篤な副反応はなかった。

病院職員に扔いても破傷風免度獲得は有益であるという認識が強く, このような高い接種率が達 成することができたと考えられた。

Key words : 破傷風, トキソイド, ワクチン

\section{はじめに}

破傷風菌は自然環境に広く存在している。破傷風は, 破傷風トキソイドにより破傷風抗体価 $0.01 \mathrm{IU} / \mathrm{mL}$ 以上 を維持しない限り, 誰にでも発症する可能性がある.

当院では受傷後, 破傷風トキリイドを接種したにもか かわらず, 基礎免疫がなかったために後日, 破傷風を発 症した患者症例を経験した。 日本では, 1968 年 4 月に ジフテリア・百日咳・破傷風の三種混合ワクチン(以下,

浜松医療センター 1) 看護部, 2) 感染症科, 3) 薬剂科, ${ }^{4}$ 臨床検 查技術科
DPT ワクチンとする)が定期接種に組反込まれた。しか し，DPT ワクチン定期接種開始前に生まれた人は，破 傷風に対する基礎免疫を獲得していない可能性が高いこ とや，DPT ワクチン定期接種者に扔いても 10 年毎に 必要とされる追加接種が実施されていないなどの問題が 指摘されている1).

破傷風免疫獲得はすべての人に対し望まれ1)，医療従 事者も外傷, 人 ·動物咬傷 2,3 , 災害活動時の備えとし て破傷風免疫を獲得しておくことが望をしい．

今回, 当院の職員に対する破傷風トキソイド接種プロ グラムを行った結果を報告する。 


\section{対象}

当院に勤務する全職員 (委託職員は除く)を対象とした.

方法

\section{1）接種回数}

DPT ワクチン定期接種開始前に生まれた人は, 破傷 風の基礎免疫獲得を目的とし, 破傷風トキソイドを 3 回接種とした.DPTワクチン定期接種開始後に生まれ た人は，DPTワクチン定期接種により破傷風の基礎免 疫を獲得していると考元, 破傷風トキソイドを 1 回追 加接種することとした，な扔，過去における DPTワク チン接種が不明の人は, 希望により破傷風トキソイド 3 回接種を可能とした.

\section{2）破傷風トキソイドの選定}

破傷風トキソイドは, デンカ生研一田辺三菱製薬侏 「沈降破傷風トキソイド 生研」を使用した。

3）破傷風トキソイド接種スケジュール

院内の他のワクチン接種スケジュールを考慮し，生ワ クチン接種後は 4 週間以上，不活化ワクチン接種後は 1 週間以上の間隔を空けて破傷風トキソイドが接種できる ように計画・実施した。

・第 1 接種日：2010 年 8 月

・第 2 接種日：2010 年 10 月

・第 3 接種日：2011 年 6 月

・第 4 接種日 : 2011 年 7 月

\section{4）接種費用}

破傷風トキソイド接種費用は, 一部病院負担とした。

\section{5）破傷風トキソイドの管理}

破傷風卜キソイド接種までの保管・管理は，薬剤科の 冷蔵庫で実施した。

\section{6）破傷風トキソイド接種不適者，要注意者の選定}

事前に予診票を配布, 接種当日に医師による問診を行 い, 破傷風トキソイド接種不適者, 要注意者の選定を行 った.

接種不適当者とは，被接種者が次のいずれかに該当す ると認められる場合とした。

（1）明らかな発熱を呈している者.

（2）重篤な急性疾患にかかっていることが明らかな者.

（3）本剤の成分によってアナフィラキシーを呈したこ とがあることが明らかな者.

（4）上記に掲げる者のほか，予防接種を行うことが不 適当な状態にある者.

接種要注意者とは，被接種者が次のいずれかに該当す ると認められる場合とした。但し，被接種者の健康状態 及び体質を勘案し, 診察及び接種適否の判断を慎重に行 い，予防接種の必要性，副反応，有用性について十分な 説明を行い，同意を確実に得た場合は，注意して接種す ることとした.
（1）心臓血管系疾患，腎臓疾患，肝臓疾患，血液疾 患, 発育障害等の基礎疾患を有する者.

（2）予防接種で接種後 2 日以内に発熱のみられた者 及び全身性発疹等のアレルギーを疑う症状を呈し たことがある者.

（3）過去に痤攣の既往のある者.

（4）過去に免疫不全の診断がなされている者及び近親 者に先天性免疫不全症の者がいる者.

（5）本剤の成分に対して，アレルギーを呈する恐れの ある者.

\section{7）破傷風トキソイド接種方法}

破傷風トキソイド接種は，テルモシリンジ $1 \mathrm{~mL}$ 予防 接種用 $25 \mathrm{G}$ を用いた。破傷風トキソイド添付文書の用 法用量に従い 1 回接種量を $0.5 \mathrm{~mL}$ とし，上腕外側に皮 下注射を実施した。

\section{8）副反応調査の実施}

破傷風トキソイド接種者に対し, 後日アンケート用紙 を用いて副反応調査を実施した。

9）インフォメーション

破傷風ワクチン接種に先立ち, 感染症科医師によるセ ミナーを開催した．その他, 破傷風と破傷風卜キソイド 接種に関する情報を書面により各部署に配布した。

\section{結果}

全職員を対象とした当院の破傷風トキソイド接種プロ グラムに抢ける破傷風トキソイド接種率は， $74.3 \%$ （754人/1021人)であった.

本プログラムにより破傷風トキソイドを接種した職員 における職種別の破傷風トキソイド接種割合は，医師 $41.1 \%$ (66 人 $/ 140$ 人), 看護師/保健師/助産師 $73.9 \%$ $(444$ 人 $/ 601$ 人)，リハビリテーション $100 \%(25$ 人 $/ 25$ 人), 診療放射線技師 $70.4 \%$ (19人 $/ 27$ 人), 歯科衛生士 $100 \%$ ( 2 人 $/ 2$ 人)，その他の職種 $87.6 \%$ (198 人 $/ 226$ 人)であった(図 1).

本プログラムで実施された接種日別にみた破傷風卜キ ソイドの 1 回目接種者と追加接種者の内訳は, 第 1 接 種日は 1 回目接種者のみで 519 人であった。第 2 接種 日は 1 回目接種者が 40 人, 追加接種者が 199 人であっ た. 第 3 接種日は 1 回目接種者が 182 人, 追加接種者 が 152 人であった。第 4 接種日は 1 回目接種者が 13 人，追加接種者が 48 人であった(図 2).

本プログラムにより破傷風トキソイドを接種した年代 別割合は 20 歳代 $29.8 \%, 30$ 歳代 $32.4 \% ， 40$ 歳代 $17.2 \% ， 50$ 歳代 $17.4 \% ， 60$ 歳代 $3.2 \%$ であった（図 3）。その内, DPT 定期接種開始前に生まれた人を含む 40 歳代以上の破傷風トキソイド接種割合は $92.8 \%$ (285/307 人)であった。DPT ワクチン定期接種開始後 に生まれた 30 歳代以下の人の破傷風トキソイド接種割 


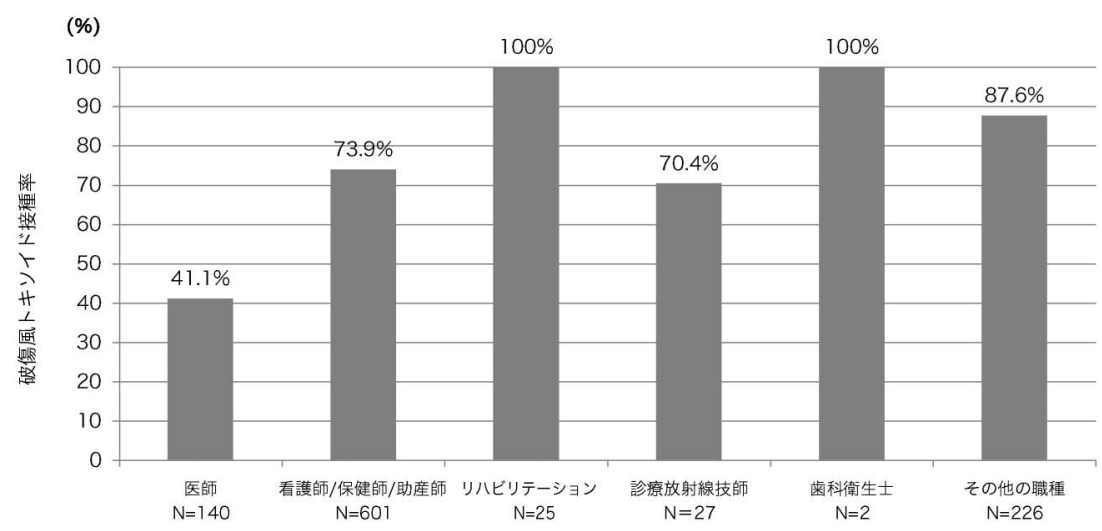

図 1 職種別にみた破傷風トキソイド接種割合

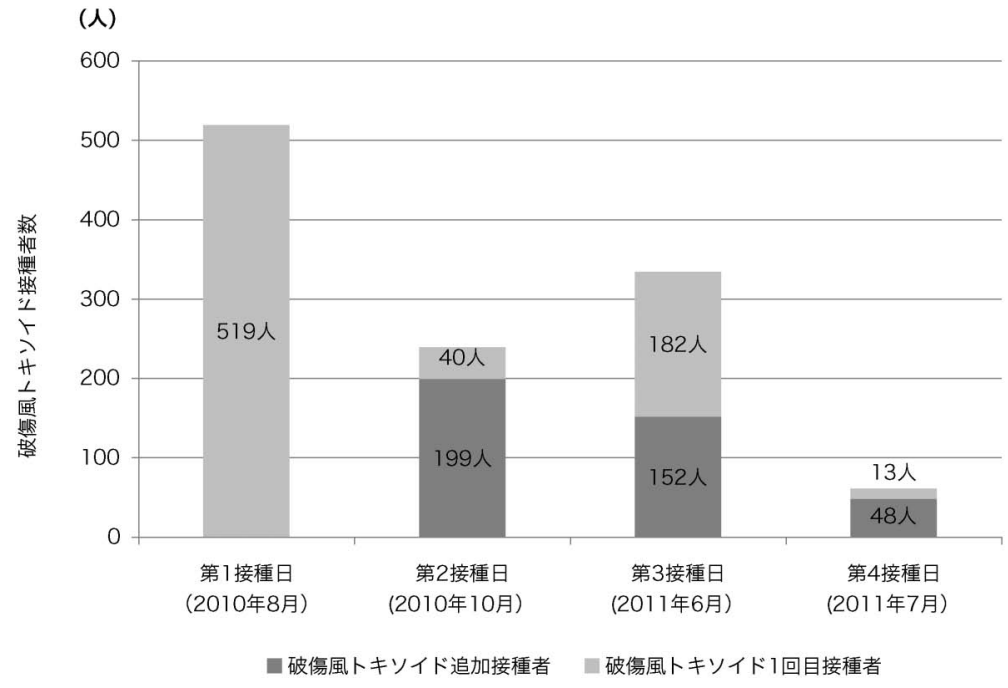

図 2 接種日別にみた破傷風トキソイド接種者数

破傷風トキソイド 1 回目接種者: 本プログラムにおける 1 回目の破傷風トキソイド接種者.

破傷風トキソイド追加接種者 : 本プログラムに打ける 2 回目, 3 回目の破傷風トキソイドを追加接種した者.

$\square 20$ 歳代 $\square 30$ 歳代 $\square 40$ 歳代 $\square 50$ 歳代 $\square 60$ 歳代

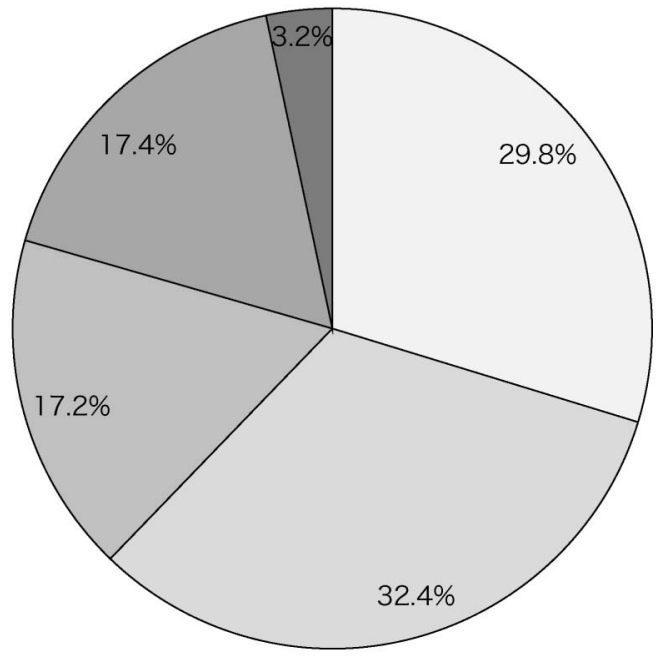

図 3 破傷風トキソイドを接種した年代別割合 $\mathrm{N}=745$
合は， $65.7 \%(469 / 714$ 人)であった.

本プログラムにより破傷風トキソイドを接種した職員 の副反応アンケート調査用紙の回収率は $59.2 \%$ であっ た. 破傷風トキソイド接種によるショック，アナフィラ キシーなどの重大な副反応発生報告はなかった。その他 の副反応として発赤 $29.3 \%$, 腫脹 $23.6 \%$, 硬結 $18.4 \%$, 疼痛 $14.2 \%$, 掻痒感 4\%の順に高かった．過去 に DPT ワクチンの接種経験のない 1 名が破傷風トキソ イドの追加接種後, 接種部位に強い発赤, 腫脹などの局 所症状が認めた。医師に相談し, 以後の追加接種を辞退 した(図4).

\section{考察}

現在，日本に抢ける破傷風の発生頻度は，DPT 定期 接種が開始されてから年間約 100 症例前後で報告され ている4)。一般人にとっても医療従事者にとっても破傷 


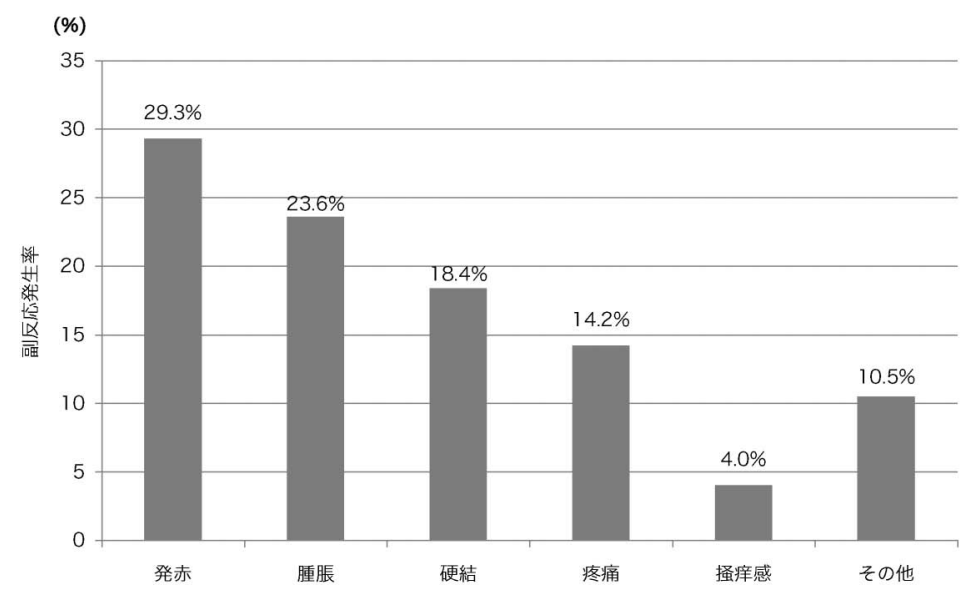

図 4 副反応発生者における副反応種類別発生割合

風は身近な疾患であると言う認識が低いことが予測され た、そこで破傷風トキソイド接種プログラムを実施する にあたり, 破傷風および破傷風トキソイドに関する事前 の情報提供が必要であると考え, 講義と書面による情報 提供を実施した。講義による情報提供は，全職員対象と し平日の夕方に実施したが，時間の制約や業務等の都合 により参加者は少なかった。より多くの職員が参加でき るように, 講義回数を増やすことや開催時間の検討が必 要であると考えられた，書面による情報提供は，各部署 に書面の配布と揭示を行った。書面であれば時間の制約 に捕らわれず，職員の空いている時間で必要な情報を得 ることができるため効果的と考えられた。この様に破傷 風と破傷風トキソイドに関する事前の情報提供が，破傷 風トキソイド接種への動機付けとなり，高い接種率につ ながったと考えられた。

破傷風トキソイドを接種した職員における職種別破傷 風トキソイド接種割合は, 患者に直接的な医療行為を実 施する職種で高い接種率が得られた。人咬傷で破傷風に 感染した事例報告が複数あることや，災害時の医療活動 時に推奨される破傷風トキソイド接種について情報提供 をしたことが効果的であったと考えられる．医師の破傷 風トキソイド接種割合は，他の職種に比べて低率であっ た．破傷風トキソイド接種に無関心であった，業務が多 忙であった，過去に破傷風トキソイドを接種していたな どが考えられた。しかし，インフルエンザワクチン接種 は多忙な業務の中でも $93.8 \%$ と高い接種率であり，医 師の破傷風トキソイド接種については今後の課題である.

接種日別にみた 1 回目破傷風トキソイド接種者数の 変化は，2011 年 6 月に実施された第 3 接種日に大幅な 増加がみられた。第 2 接種日から第 3 接種日までの間 に新たな情報提供は行っていない。この理由としては, 東日本大震災の二ュースの影響, またこの間の新規採用 者が多く破傷風トキソイドを希望したことがあげられ
る.マスメディアからもたらされる災害医療活動現場の 映像や，瓦碟撤去作業が原因と考えられる被災地での破 傷風患者発生などの追加情報により，破傷風に対する免 疫獲得の必要性が再認識され, 破傷風トキソイド接種増 加に繋がったのではないかと考えられた.

破傷風トキソイドを接種した年代別割合において， DPT 定期接種開始前に生まれた人を含む 40 歳代以上 で, $92.8 \%(285 / 307$ 人) と高い接種率を得ることが出来 た. 河野ら ${ }^{5)}$ 山崎ら ${ }^{6)}$ の研究では, 40 歳代以上の多くの 人が破傷風抗体 $0.01 \mathrm{IU} / \mathrm{mL}$ 以上の免疫を持たないと報 告されて，2004～2008 年感染症発生動向調査に報告さ れた破傷風患者 546 人の内 $94 \%$ (513 人) が 40 歳以上で あった．本プログラムにより破傷風トキソイド 3 回接 種を実施したことで，DPT 定期接種開始前の人に対し 破傷風基礎免疫獲得が期待され，感染予防に効果がある と考えられる.DPT ワクチン定期接種開始後に生まれ た 30 歳代以下の接種率は, $65.7 \%(469 / 714$ 人)であっ た. 2004 2008 年感染症発生動向調査では, 30 歳代以 下の報告もあることから 10 年毎に必要とされる破傷風 トキソイド追加接種が実施できたことで, 破傷風免疫の 強化が図れたと考えられた.

破傷風トキソイド接種者に抢ける副反応は，接種部位 の発赤, 腫脹, 硬結など局所的な報告が多かった. 今回 のアンケート調査では, 過去に破傷風に対し基礎免疫を 持つ人と持たない人で, 副反応発生の頻度や程度に違い があるかは不明である。しかし，一般的に基礎免疫を持 つ人の方が追加接種による抗原抗体反応が強く現れる傾 向にあり，副反応に関する情報提供と接種後の経過観察 が必要と考えられる. 過去に DPT ワクチンを接種した 経験のない 1 名に追加接種後, 強い発赤, 腫脹などの 局所症状が認められ, 医師に相談し以後の追加接種を辞 退した。接種者はアレルギー体質であるとのことから， 強い副反応を呈したと考えられた．いずれの副反応も数 
日で自然軽快しており，治療を必要とする副反応の発生 はなく安全に破傷風トキソイド接種を行うことができた.

$\mathrm{CDC}$ は1)「破傷風に対する免疫は, 全ての人に持つ ことが望まれる免疫の一つである」と述べており, 日本 では小児期に DPT ワクチン定期接種を実施している. しかし，DPT ワクチン定期接種がなかった 1968 年 4 月より前に生まれた人, 何らかの理由により DPT ワク チン定期接種を逃した人, 10 年毎の追加接種を実施し ていない人にとってキャッチアップを行う機会は少な い，破傷風トキソイド接種の機会がなければ，抗体価の 低下に伴い破傷風に対して無防備な状態となる恐れがあ る。そのような機会を設けることが出来る破傷風トキソ イド接種プログラムは, 職員における破傷風免疫獲得に とって有益であり，このような高い接種率を達成するこ とができた。

利益相反について : 利益相反はない.

\section{文献}

1) http://www.cdc.gov/mmwr/pdf/rr/rr6007.pdf

2) Agrawal K, Ramachandrudu T, Hamide A, Dutta TK: Tetanus caused by human bite of the finger. Ann Plast Surg 1995; 34(2): 201-2.

3) Muguti GI, Dixon MS: Tetanus following human bite. Br J Plast Surg 1992; 45(8): 614-5.

4）佐藤信博, 遠藤重厚：救急薬品の正しい使い方 破傷 風. 救急医 $2003 ; 27(4): 486-90$.

5）河野喜美子, 東 美香: 平成 15 年度ジフテリア・破傷 風・百日咳抗体保有状況調査成績. 宮崎衛環境研年報 2004; 15: 50-6.

6）山崎史子, 永田暁洋, 石 胡史, 浅田恒夫 : 2008 年度 感染症流行予測調査結果〜ジフテリア・百日咳・破傷 風〜．福井衛環境研セ年報 2009; 7: 98-102.

〔連絡先：テ432-8580 静岡県浜松市中区富塚町 328 浜松医療センター看護部 葛原健太 E-mail:k.kenta@hmedc.oe.jp]

\title{
Vaccination Program of Tetanus Toxoid for Staff
}

\author{
Kenta Kuzuhara $^{1)}$, Yasuko Matsui ${ }^{1)}$, Yosiko MiYazaki ${ }^{1)}$, Mititsugu Simatani ${ }^{2)}$, \\ Misaki TAKAmiYa $^{2)}$, Norimasa IshiI ${ }^{3)}$, Tomoko HorIUTI ${ }^{4)}$ and Kunio YANO ${ }^{2)}$ \\ ${ }^{1)}$ Department of Nursing, ${ }^{2)}$ Department of Infectious Disease and Infection Control, ${ }^{3)}$ Department of Pharmacy, \\ ${ }^{4)}$ Department of Clinical Laboratory, Hamamatsu Medical Center
}

\begin{abstract}
Acquisition of tetanus immunity is expected to occur in all people. Induction of tetanus immunity is desirable as a precaution after a bite or disaster activity from a patient in healthcare workers. Tetanus toxoid inoculation program was carried out for our staff. Individuals born before April 1968, when the diphtheria, pertussis, and tetanus (DPT) vaccination was introduced, were given three inoculations of tetanus toxoid. Individuals born after April 1968 were given one inoculation, and individuals who could not remember previous DPT vaccination were given three inoculations, if requested. Immunization coverage in this program was $74.3 \%(754 / 1021)$, which seemed to be high regardless of occupational groups. In the first day of the program, half of our entire staff were given tetanus toxoid. Immunization coverage rate by age was about $30 \%$ in the twenties and thirties group; $17 \%$ in the forties and fifties group, and $3 \%$ in the sixties group. The coverage rate was $92.8 \%(285 / 307)$ in all staff aged more than 40 s including a person born before DPT commuter pass inoculation start. The coverage rate was $65.7 \%(469 / 714)$ in staff aged less than 30 s born after DPT vaccine commuter pass inoculation. Adverse reactions of local redness and swelling were observed frequently without severe reaction. Acquisition of tetanus immunity is strongly recognized as useful in hospital personnel, resulting in such a high inoculation rate.
\end{abstract}

Key words : tetanus, toxoid, vaccine 